\title{
Postabsorptive carbohydrate adaptations to heat stress and monensin supplementation in lactating Holstein cows ${ }^{1}$
}

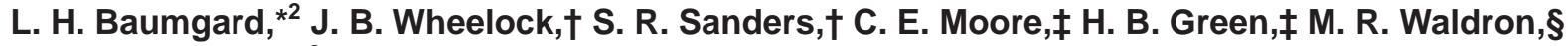 \\ and R. P. Rhoads $t^{3}$ \\ *Department of Animal Science, lowa State University, Ames 50011 \\ †Department of Animal Sciences, The University of Arizona, Tucson 85721 \\ ‡Elanco Animal Health, Greenfield, IN 46140 \\ $\S$ Department of Animal Sciences, University of Missouri, Columbia 65211
}

\begin{abstract}
Multiparous cows $(\mathrm{n}=34,89 \mathrm{~d}$ in milk, $537 \mathrm{~kg}$ ) housed in environmental chambers were fed a control total mixed ration or one containing monensin (450 $\mathrm{mg} /$ cow per day) during 2 experimental periods $(\mathrm{P})$ : (1) thermal neutral (TN) conditions (constant $20^{\circ} \mathrm{C}$ ) with ad libitum intake for $9 \mathrm{~d}$, and (2) heat stress (HS, $\mathrm{n}=16)$ or pair-fed [PF; in TN (PFTN); $\mathrm{n}=18]$ for $9 \mathrm{~d}$. Heat-stress was cyclical with temperatures ranging from 29.4 to $38.9^{\circ} \mathrm{C}$. Rectal temperatures and respiration rates increased in HS compared with PFTN cows (38.4 to $40.4^{\circ} \mathrm{C}, 40$ to $\left.93 \mathrm{breaths} / \mathrm{min}\right)$. Heat stress reduced dry matter intake (DMI, 28\%), and by design, PFTN cows had similar intakes. Monensin-fed cows consumed less DMI $(1.59 \mathrm{~kg} / \mathrm{d})$ independent of environment. Milk yield decreased $29 \%(9.1 \mathrm{~kg})$ in HS and $15 \%(4.5 \mathrm{~kg})$ in PFTN cows, indicating that reduced DMI accounted for only $50 \%$ of the decreased milk yield during HS. Monensin had no effect on milk yield in either environment. Both HS and PFTN cows entered into calculated negative energy balance $(-2.7 \mathrm{Mcal} / \mathrm{d})$, and feeding monensin increased feed efficiency $(7 \%)$ regardless of environment. The glucose response to an epinephrine (EPI) challenge increased (27\%) during P2 for both HS and PFTN cows, whereas the nonesterified fatty acid response to the EPI challenge was larger (56\%) during P2 in the PFTN compared with the HS cows. Compared with P1, whole-body glucose rate of appearance (Ra) decreased similarly during P2 in both HS
\end{abstract}

\footnotetext{
Received April 18, 2011.

Accepted July 15, 2011.

${ }^{1}$ This work was partially funded by Elanco Animal Health, the National Milk Producers Federation, and The University of Arizona Experiment Station, \#ARZT-136339-H-24-130. This project was supported by National Research Initiative Competitive Grant no. 2008-35206-18817 and Agriculture and Food Research Initiative Competitive Grant no. 2010-65206-20644 from the USDA National Institute of Food and Agriculture.

${ }^{2}$ Corresponding author: baumgard@iastate.edu

${ }^{3}$ Current address: Department of Animal and Poultry Sciences, Virginia Polytechnic Institute and State University, Blacksburg 24061.
}

and PFTN cows (646 vs. $514 \mathrm{mmol} / \mathrm{h}$ ). Although having similar rates of glucose Ra, HS cows synthesized approximately $225 \mathrm{~g}$ less milk lactose; therefore, on a milk yield basis, glucose Ra decreased (3.3\%) in PFTN but increased $(5.6 \%)$ in HS cows. Regardless of environment, monensin-fed cows had increased $(10 \%)$ glucose Ra per unit of DMI. From the results we suggest that the liver remains sensitive but adipose tissue becomes refractory to catabolic signals and that glucose Ra (presumably of hepatic origin) is preferentially utilized for processes other than milk synthesis during HS.

Key words: heat stress, metabolism, monensin, insulin

\section{INTRODUCTION}

Despite advances in environmental management and cooling systems (Burgos et al., 2007), heat stress continues to be a costly issue for the global animal agriculture industries (St. Pierre et al., 2003). Factors contributing to reduced revenue include decreased milk production, increased metabolic disorders and health problems (e.g., rumen acidosis, death), slow heifer growth, compromised milk quality, and reduced reproductive performance (Collier et al., 1982; West, 1999). Heat stress markedly reduces DMI and milk yield and it was traditionally accepted that reduced nutrient intake was primarily responsible for the diminished milk synthesis (see reviews by Fuquay, 1981; Beede and Collier, 1986; West, 1999). However, we have recently demonstrated (using a pair-feeding experimental design) that reduced feed intake accounts for only about $50 \%$ of the heat stress-induced decrease in milk synthesis (Rhoads et al., 2009; Wheelock et al., 2010). This illustrates that an environmental thermal load directly affects milk yield by mechanisms independent of reduced nutrient intake.

A key component of the direct effect of heat stress appears to be on postabsorptive energetics. For example, we recently demonstrated that heat-stressed cows do not display the typical metabolic profile (i.e., 
increased NEFA levels) of an animal on a lowered plane of nutrition (Shwartz et al., 2009) and this is especially noticeable when compared with pair-fed thermal neutral controls (Rhoads et al., 2009; Wheelock et al., 2010). Furthermore, heat-stressed cows are typically hypoglycemic and have increased glucose disposal rates, both of which may be explained by increased basal and glucose-stimulated insulin levels (Itoh et al., 1998; O'Brien et al., 2010; Wheelock et al., 2010). We propose that enhanced extra-mammary tissue glucose utilization may be a key mechanism explaining the decrease in milk yield during heat stress. Two glucose molecules are the substrate for lactose (the primary osmotic regulator of milk yield) synthesis and, on a molar basis, lactose is nearly equivalent (95\%) to $2 \mathrm{~mol}$ of glucose. Heat-stressed cows secrete about $370 \mathrm{~g}$ less lactose (Rhoads et al., 2009) or have approximately twice as much of a decrease in milk lactose yield compared with pair-fed thermal neutral controls (Wheelock et al., 2010). Therefore, heat-stressed cows in our previous experiments are secreting almost $400 \mathrm{~g}$ less glucose/d than thermal neutral counterparts on a similar plane of nutrition.

An alternative explanation for the decrease in milk carbohydrate output is heat-induced liver dysfunction, which has been suggested in previous reports (Ronchi et al., 1999; Bernabucci et al., 2010). Hepatic dysfunction may be manifested by changes in responsiveness to nutrient supply or endocrine regulators, as has recently been demonstrated in the case of growth hormone (Rhoads et al., 2010). Such changes would directly affect the liver's ability to coordinate whole-body nutrient flux by altering key metabolic pathways such as gluconeogenesis. Indeed, recent reports indicate that HS causes hepatic gluconeogenic gene expression changes perhaps associated with different precursor supply (Rhoads et al., 2011). Consequently, reduced milk lactose output during a heat load may simply reflect altered rates of hepatic gluconeogenesis, which would ultimately reduce glucose delivery to the mammary gland.

Monensin is a well-described rumen modifier that increases the production of propionate (Schelling, 1984), the predominant gluconeogenic precursor in ruminants (Huntington, 1990). Feeding monensin increases gluconeogenic rates in beef cattle (Schelling, 1984), and although it presumably acts similarly in lactating dairy cows, it has not been as extensively evaluated as in feedlot animals. The increase in carbon conservation during fermentation is a key mechanism in how monensin increases feed efficiency in growing and lactating ruminants (Schelling, 1984).

We hypothesize that inadequate glucose status (via reduced gluconeogenesis or increased extra-mammary glucose utilization) compromises animal well-being and limits milk synthesis during periods of acute heat stress. Study objectives were to evaluate the ability of monensin to increase gluconeogenesis and glucose homeostatic parameters during heat stress.

\section{MATERIALS AND METHODS}

\section{Animals and Experimental Design}

Thirty-six multiparous ( $2.0 \pm 0.0$ parity), lactating Holstein cows $(89.2 \pm 8.1$ DIM, $537.2 \pm 41.0 \mathrm{~kg}$ of BW) were randomly assigned to individual tie stalls in 1 of 2 environmental chambers (6 cows/chamber) at the University of Arizona's William J. Parker Agricultural Research Complex. Throughout the experiment, cows were milked twice daily (0500 and $1700 \mathrm{~h}$ ) and milk yields were recorded at each milking. All cows were individually fed a TMR twice daily (0500 and $1700 \mathrm{~h}$ ), and orts were recorded daily before the a.m. feeding. The TMR was formulated by Dairy Nutrition Services (Chandler, AZ) to meet or exceed the predicted requirements (NRC, 2001) of energy, protein, minerals, and vitamins (Table 1). Alfalfa hay was the primary forage, with steam-flaked corn as the primary concentrate. The TMR was sampled weekly and analyzed by wet chemistry methods (Dairy Nutrition Services). All procedures were reviewed and approved by the University of Arizona Institutional Animal Care and Use Committee.

All cows received 1 of 2 dietary treatments: (1) control TMR containing $0 \mathrm{mg}$ of monensin/cow per day $(\mathrm{n}=$ 17) or (2) the control TMR top-dressed with monensin (Rumensin, Elanco Animal Health, Greenfield, IN) tar-

Table 1. Ingredients and chemical composition of $\operatorname{diets}^{1}$

\begin{tabular}{lc}
\hline Item & Value \\
\hline Ingredient, \% of DM & \\
Alfalfa hay & 63.0 \\
Steam-flaked corn & 24.2 \\
Whole cotton seed $^{2}$ & 8.0 \\
Supplement $^{2}$ & 3.4 \\
Maxxer $^{3}$ & 1.1 \\
Chemical analysis, \% of DM & \\
CP & 18.8 \\
NDF & 37.6 \\
ADF & 27.5 \\
NE & 1.74 \\
\hline
\end{tabular}

${ }^{1}$ Values represent an average of samples $(\mathrm{n}=3)$ collected throughout the trial ( $\mathrm{n}=1 /$ replicate). Diet DM averaged $48.2 \%$.

${ }^{2}$ The supplement contained $1.14 \%$ fat, $10.42 \% \mathrm{Ca}, 4.49 \% \mathrm{P}, 3.80 \%$ $\mathrm{Mg}, 0.49 \% \mathrm{~S}, 0.19 \% \mathrm{~K}, 15.83 \% \mathrm{Na}, 7.52 \% \mathrm{Cl}, 2,029.06 \mathrm{mg} / \mathrm{kg}$ of $\mathrm{Zn}$, $1,991.82 \mathrm{mg} / \mathrm{kg}$ of Mn, $974.24 \mathrm{mg} / \mathrm{kg}$ of Fe, $583.45 \mathrm{mg} / \mathrm{kg}$ of $\mathrm{Cu}, 67.86$ $\mathrm{mg} / \mathrm{kg}$ of Co, $12.28 \mathrm{mg} / \mathrm{kg}$ of Se, $6.81 \mathrm{mg} / \mathrm{kg}$ of Mo, $43.68 \mathrm{mg} / \mathrm{kg}$ of $\mathrm{I}, 304.9 \mathrm{IU} / \mathrm{g}$ of vitamin A, $30.2 \mathrm{IU} / \mathrm{g}$ of vitamin $\mathrm{D}$, and $1.0 \mathrm{IU} / \mathrm{g}$ of vitamin E.

${ }^{3}$ Calcium salts of palm oil (Tarome Inc., Eloy, AZ). 
geted at $450 \mathrm{mg} /$ cow per day $(\mathrm{n}=17)$ for $19 \mathrm{~d}$ before entering the climatic chambers. After entering the climatic chambers, cows were allowed $3 \mathrm{~d}$ for acclimation. Cows in both dietary treatment groups were exposed to constant thermal neutral (TN) conditions $\left[20^{\circ} \mathrm{C}, 20 \%\right.$ humidity (temperature-humidity index, $\mathbf{T H I}=64$ ) with 14-h light and 10-h dark cycles] and allowed to eat ad libitum for $9 \mathrm{~d}$ [experimental period $(\mathbf{P})$ 1]. Period 1 and P2 were separated by $2 \mathrm{~d}$ and cows remained in TN conditions during this time. During P2 (9 d), cows in both dietary treatment groups either remained under the TN conditions $(\mathrm{n}=18$; group 1 cows) or were heat-stressed (HS; $\mathrm{n}=16$; group 2 cows). Two cows from the HS group (1 control and 1 monensin) were removed from the trial for temperament issues, and their respective data were not included in the analysis. The HS cows endured cyclical temperatures (in an attempt to mimic daily variation) ranging from 29.4 to $38.9^{\circ} \mathrm{C}$ with constant $20 \%$ humidity and 14-h light and 10-h dark cycles and were fed for ad libitum consumption. Between 0000 and $0700 \mathrm{~h}$, the THI remained at 73; thereafter, the conditions became increasingly warm until peaking at a THI of 82 between 1300 and $1500 \mathrm{~h}$. After peak THI, temperatures gradually declined until the THI again reached 73 at $2300 \mathrm{~h}$. Reductions in P2 daily feed intake by HS cows were determined as a percentage of their mean daily ad libitum intake in P1. Cows in group 1 were pair-fed (PF) in $\mathrm{TN}$ conditions (PFTN) during P2 to match the percentage reduction in intake of the HS cows. Initiation of P2 for the PF cows occurred $2 \mathrm{~d}$ after P2 began for the HS cows so that the percentage reduction in daily feed intake of the HS cows could be calculated and used to determine the amount offered to the PF cows in TN conditions.

\section{Thermal Status Measurements}

Body temperature indices (respiration rate, skin and rectal temperatures) were obtained 3 times daily (0600, 1500 , and $1800 \mathrm{~h}$ ). Respiration rates were determined by counting flank movements, and skin temperatures were measured on a shaved patch (approximately 5 $\mathrm{cm}^{2}$ ) on the shoulder with an infrared temperature gun (Raynger MX model RayMX4PU, Raytek, Santa Cruz, CA). Rectal temperatures were measured using a standard digital thermometer (GLA M700 Digital Thermometer, GLA, San Luis Obispo, CA).

\section{Milk and Blood Sampling}

Milk samples from each cow (from the morning milking) were collected daily from each period and stored at $4^{\circ} \mathrm{C}$ with a preservative (bronopol tablet; D\&F Control System, San Ramon, CA) until analysis by Ari- zona DHIA (Tempe, AZ) using AOAC (2000)-approved infrared analysis equipment and procedures for milk components.

Bilateral indwelling jugular catheters were inserted into all cows before P1. Blood samples were collected daily at $1100 \mathrm{~h}$ during both periods from the jugular catheter into evacuated glass tubes containing 250 units of sodium heparin (BD Vacutainer, Franklin Lakes, NJ). Plasma was harvested following centrifugation at $1,500 \times g$ for $15 \mathrm{~min}$, and subsequently frozen at $-20^{\circ} \mathrm{C}$ until analysis.

\section{Net Energy Balance Analysis}

Body weights were obtained on all animals on $\mathrm{d}$ $1,3,4,5$ and 9 of each period following the morning milking and before the a.m. feeding and were used to calculate net energy balance (EBAL) using the following equation: $\mathrm{EBAL}=$ net energy intake $-\left(\mathrm{NE}_{\mathrm{M}}+\right.$ $\mathrm{NE}_{\mathrm{L}}$ ). Maintenance energy requirement was calculated using the equation $\mathrm{NE}_{\mathrm{M}}=\left(0.08 \times \mathrm{BW}^{0.75}\right.$; $\left.\mathrm{NRC}, 2001\right)$ and was increased by $25 \%$ during the HS conditions as recommended (NRC, 1989). Net energy for lactation was calculated as $\mathrm{NE}_{\mathrm{L}}=[(0.0929 \times$ fat \% $)+(0.0547$ $\times \mathrm{CP} \%)+(0.0395 \times$ lactose $\%)] \times$ milk yield $(\mathrm{NRC}$, 2001). The following equations (NRC, 2001) were used to calculate $3.5 \%$ FCM: $3.5 \%$ FCM $=(0.432 \times$ milk yield $)+(16.23 \times$ milk fat yield $)$. Feed efficiency was calculated using the following equation: feed efficiency $=3.5 \% \mathrm{FCM} / \mathrm{DMI}$.

\section{Whole-Body Glucose Production}

Whole-body glucose production was determined on d 6 of each period using a primed, continuous infusion $(14 \mu \mathrm{mol} / \mathrm{kg}$ priming dose followed by 11.5 $\mu \mathrm{mol} \cdot(\mathrm{kg} \cdot \mathrm{h})^{-1}$ stable isotopically labeled glucose, 6,6-dideuterated glucose, D2-glucose; Sigma Aldrich, St. Louis, MO) and tracer kinetic methodologies as described previously (Waldron et al., 2006). A baseline (0 min) blood sample was obtained via a jugular catheter at approximately $1200 \mathrm{~h}$ (approximately $6 \mathrm{~h}$ after the morning feeding) and the primed, continuous infusion (3M 3000 Modular Infusion Pump, 3M Health Care, St. Paul, MN) of D2-glucose tracer began immediately thereafter. Blood samples were obtained at $165,180,195$, and $210 \mathrm{~min}$ after the priming dose for the subsequent determination of plasma glucose enrichment with D2-glucose. The continuous D2-glucose infusion was terminated immediately after the $210 \mathrm{~min}$ blood sampling. Blood was centrifuged at $1,500 \times g$ for $15 \mathrm{~min}$, and plasma was harvested and stored at $-20^{\circ} \mathrm{C}$ until isotopic analysis. 


\section{Isotopic Analysis}

Plasma glucose enrichment of D2-glucose and the subsequent calculation of plasma glucose rate of appearance (Ra) were performed as described previously (Waldron et al., 2006). Enrichment was measured in samples from the $0,165,180,195$, and 210 min time points. Frozen plasma was thawed, deproteinized using acetone, and derivatized to the butyl boronate derivative as discussed by Weiko and Sherman (1976). Plasma D2-glucose enrichment was determined by GC-MS (col$\mathrm{umn}=30 \mathrm{~m}$ DB1, 0.25-mm ID, 0.25- $\mu \mathrm{m}$ film thickness, split ratio was $60: 1$, flow at $1 \mathrm{~mL} / \mathrm{min}$, injector port temperature was $272^{\circ} \mathrm{C}$, oven temperature was $232^{\circ} \mathrm{C}$; MS conditions: SIM ions 299/297 in EI mode, expected retention time of $4.0 \mathrm{~min}$ ).

\section{Glucose Tolerance Test}

A glucose tolerance test (GTT; $250 \mathrm{mg} / \mathrm{kg}$ of BW) was administered to all cows, as described previously by Wheelock et al. (2010), on d 7 of each period at 1200 h. A 50\% dextrose solution (AGRIpharm Products, Grapevine, TX) was administered via the jugular catheter and immediately flushed with $12 \mathrm{~mL}$ of sterile saline. Blood samples were collected at $-30,-20$, $-10,0,5,7.5,10,20,30,45,60$, and 90 min relative to glucose administration. Samples were collected into disposable glass culture tubes, containing 250 units of sodium heparin and immediately placed on ice. After centrifugation, plasma was split into 2 aliquots, which were both frozen at $-20^{\circ} \mathrm{C}$, and 1 aliquot was later analyzed for plasma glucose and insulin concentrations.

\section{Epinephrine Challenge}

Epinephrine challenges (EPI; $1.4 \mu \mathrm{g} / \mathrm{kg}$ of BW) were administered, as described previously by Baumgard et al. (2002), on d 8 of each period at $1200 \mathrm{~h}$. Epinephrine $\mathrm{HCl}(1 \mathrm{mg} / \mathrm{mL}$; Anpro Pharmaceutical, Arcadia, CA) was administered via the jugular catheter and immediately flushed with $12 \mathrm{~mL}$ of sterile saline. Blood samples were collected at $-30,-20$, $-10,0,2.5,5,7.5,10,20,30,45,60,90$, and 120 min relative to epinephrine administration. Samples were collected by syringe into disposable glass culture tubes containing 250 units of sodium heparin and immediately placed on ice. After centrifugation, plasma was divided into 2 aliquots, which were both frozen at $-20^{\circ} \mathrm{C}$ for subsequent analysis of plasma NEFA and glucose concentrations.

\section{Plasma Analyses}

All plasma glucose, NEFA, and plasma urea N (PUN) concentrations were measured enzymatically using commercially available kits validated for use in our laboratory (Autokit Glucose C2; Wako Chemicals USA, Richmond, VA; NEFA C kit; Wako Chemicals USA; PUN, Urease, Color Endpoint kit; Advanced Bio-Screen, Fullerton, CA). The insulin assays were conducted in duplicate using a bovine insulin ELISA (Mercodia AB, Uppsala, Sweden). The intra- and interassay CV were 3.72 and $3.40,2.62$ and $2.47,6.25$ and 7.16, and 3.02 and $2.77 \%$ for glucose, NEFA, PUN, and insulin assays, respectively.

\section{Calculations}

The glucose and insulin responses to the GTT and the glucose and NEFA response to the epinephrine challenge were calculated as area under the curve (AUC) by use of linear trapezoidal summation between successive pairs of respective metabolite or hormone concentrations and time coordinates after correcting for the mean baseline levels (Baumgard et al., 2002). Baseline concentrations were defined as the mean of the 3 samples before the GTT or epinephrine administration. The AUC was determined for 30-, 45-, 60-, and 90-min intervals after the GTT or epinephrine administration, and statistical and biological interpretation of these results did not differ among the intervals. In response to the GTT, the glucose AUC was reported from 0 to $60 \mathrm{~min}$ and the insulin response was reported from 0 to $45 \mathrm{~min}$. In response to the EPI challenge, the NEFA AUC was reported from 0 to $45 \mathrm{~min}$ and glucose AUC reported from 0 to $90 \mathrm{~min}$.

\section{Enrichment}

Calculation of plasma glucose enrichment with D2glucose at each time point was performed as described previously (Waldron et al., 2006). Briefly, a set of known standards composed of different concentrations of D2glucose relative to unlabeled glucose was prepared and analyzed by GC-MS. The ratio of (mass +2$) /$ mass glucose fragments versus mole fraction (mol of labeled glucose $\times$ mol of unlabeled glucose ${ }^{-1}$ ) of 6,6 -D2-glucose was plotted to serve as standards for the GC-MS analysis. The ratios of (mass +2$) /$ mass glucose fragments in derivatized samples were determined and the percent mole fraction determined relative to the known standards. The $0 \mathrm{~min}$ percent mole fraction (natural basal enrichment of plasma glucose with D2-glucose) 
was subtracted from values for all other time points for each cow to yield the measure of enrichment, the percent mole fraction excess (also called atom percent excess or mole percent excess).

\section{Kinetics}

Under steady-state conditions, the rate of glucose appearance (Ra) equals rate of disappearance. The Ra was calculated by dividing the tracer (D2-glucose) infusion rate by plasma enrichment (mole percent excess) at isotopic steady state and then subtracting the amount of tracer infused from the total rate of appearance. This subtraction is necessary to correct for infused tracer mass because stable isotope tracers must be infused at higher rates than radiolabeled tracers and thus cannot be considered mass-less.

\section{Statistical Analysis}

The $2 \times 2 \times 2$ factorial design included 9 controls and 9 monensin-fed cows in the PF treatment and 8 controls and 8 monensin-fed cows in the HS treatment. Twelve cows were housed in the environmental chambers at one time, and 3 replicates were necessary to conduct the entire experiment. Effects of replication $(1,2$, or 3$)$, diet (control or monensin), period (1 or 2 ), and group (pair-fed vs. heat stress) and their interactions were assessed as a completely randomized design using PROC MIXED (SAS Institute, 2005). A repeated-measures analysis with an autoregressive covariance structure and day as the repeated effect was used to determine effects of day, diet, period, and group, and their interaction on repeated measurements (e.g., DMI, milk yield, daily metabolites). Interactions were removed from the model if their respective $P>$ 0.15 . Results are reported as least squares means and means were considered to differ when $P \leq 0.05$ and tended to differ if $P<0.10$.

\section{RESULTS}

Few or no group differences were observed in body temperature indices during P1 (when all cows were housed in TN conditions), but at 0600, 1500, and 1800 $\mathrm{h}$ during $\mathrm{P} 2$, rectal temperatures and respirations rates were markedly increased $(P<0.01$; Table 2$)$ in group 2 (HS) cows. Maximum differences between group 1 (PFTN) and group 2 cows in rectal temperature $\left(2.0^{\circ} \mathrm{C}\right)$ and respiration rate ( $\sim 53$ breaths $/ \mathrm{min})$ occurred at $1500 \mathrm{~h}$ (Table 2). Overall and compared with controls, monensin-fed cows had increased $(P<0.01)$ rectal temperatures and this increase averaged $0.18^{\circ} \mathrm{C}$ during the entire experiment (Table 2). Compared with controls, monensin-fed cows had an overall increase $(P=0.02$;
Table 2) in respiration rates at 0600 and $1800 \mathrm{~h}$, but this was due to the difference $(\sim 8.7$ breaths $/ \mathrm{min})$ during P2. During P2, control and monensin-fed cows had similar respiration rates at $1500 \mathrm{~h}$ (Table 2).

A group effect was detected on DMI $(P<0.01$; Table $3)$ as group 2 cows consumed more $(\sim 1.8 \mathrm{~kg} / \mathrm{d})$ feed than group 1 cows, but this difference existed in $\mathrm{P} 1$ and continued in P2. During P2, HS conditions decreased $(P<0.01)$ feed intake similarly between control and monensin-fed cows (Table 3). By d 7 to 9 of P2, HS decreased DMI by $5.86 \mathrm{~kg}$ and, by design, PFTN cows had a similar reduction $(5.85 \mathrm{~kg}$ ) in DMI (data not shown). Overall, cows fed monensin consumed less $(1.59 \mathrm{~kg} / \mathrm{d} ; P<0.01)$ DM than control-fed cows (Table 3 ). The differences between main and interaction effects and the temporal pattern of decreased DMI were similar when evaluated on a BW basis (Table 3).

Compared with P1, during P2, group 1 and 2 cows had decreased $(P<0.01)$ milk production (Table 3$)$. However, by d 7 to 9 of P2, PFTN cows had a reduction of $4.46 \mathrm{~kg}(15 \%)$ in milk yield, whereas those under HS conditions (group 2) had a decrease of $9.09 \mathrm{~kg}(29.4 \%$; data not shown). No main effects of diet $(P>0.50)$ were observed, but monensin-fed cows tended to have a more severe decrease in milk yield (regardless of group) during P2 (2.33 vs. $5.91 \mathrm{~kg} ; P=0.08)$. The changes in $3.5 \%$ FCM due to treatment were similar to those for actual milk yield, except that monensin and controlfed cows had a comparable reduction $(3.68 \mathrm{~kg})$ in milk yield during P2 (Table 3). In addition, milk yield as a percentage of $\mathrm{BW}$ changed similarly to actual milk yield, although a group effect $(P=0.02)$ was found, as group 1 cows produced more milk (5.56 vs. $5.26 \%$ ), but this difference existed in P1 and continued during P2 (Table 3).

Milk fat content from cows in both groups fed either diet increased $(P<0.01)$ similarly during P2 (3.62 vs. $3.87 \%$; Table 3$)$. An overall diet effect $(P<0.01)$ was found on milk fat percentage, as monensin-fed cows had reduced levels (3.85 vs. 3.63\%; Table 3). Milk protein content did not differ between groups, but decreased $(P$ $<0.01$ ) during P2 compared with P1 (2.66 vs. 2.55\%; Table 3). Overall and compared with control-fed cows, monensin-fed cows had reduced $(P<0.01)$ milk protein levels (2.65 vs. $2.56 \%$; Table 3 ). Compared with group 2 , group 1 cows tended $(P=0.10)$ to have reduced milk lactose content ( 4.75 vs. $4.81 \%$; Table 3 ), but this difference existed in P1 and continued during P2. Overall, milk SNF decreased during P2 (8.40 vs. $8.22 \%$; Table $3)$ and was decreased $(P=0.02)$ in monensin-fed cows (8.38 vs. $8.24 \%$; Table 3 ).

A period effect was observed on EBAL, as cows were in positive EBAL during $\mathrm{P} 1$ but entered negative EBAL during P2 (3.31 vs. $-2.71 \mathrm{Mcal} / \mathrm{d}$; Table $3 ; P<0.01$ ) 
Table 2. Effects of diet (control or monensin) and environment (pair-feeding or heat stress) on heat parameters in lactating Holstein cows ${ }^{1}$

\begin{tabular}{|c|c|c|c|c|c|c|c|c|c|c|c|c|c|c|c|c|}
\hline \multirow[b]{3}{*}{ Parameter } & \multicolumn{4}{|c|}{ Period (Per) 1} & \multicolumn{4}{|c|}{ Period 2} & \multirow[b]{3}{*}{ SEM } & \multirow{2}{*}{\multicolumn{7}{|c|}{$P$-value }} \\
\hline & \multicolumn{2}{|c|}{$\begin{array}{c}\text { Group (Grp) } 1 \\
\text { (TN) }\end{array}$} & \multicolumn{2}{|c|}{$\begin{array}{l}\text { Grp } 2 \\
(\mathrm{TN})\end{array}$} & \multicolumn{2}{|c|}{$\begin{array}{c}\text { Grp } 1 \\
(\text { PFTN) }\end{array}$} & \multicolumn{2}{|c|}{$\begin{array}{c}\text { Grp } 2 \\
(\mathrm{HS})\end{array}$} & & & & & & & & \\
\hline & Con & Mon & Con & Mon & Con & Mon & Con & Mon & & $\begin{array}{l}\text { Grp } \\
(\mathrm{G})\end{array}$ & Per $(\mathrm{P})$ & $\begin{array}{l}\text { Diet } \\
\text { (D) }\end{array}$ & $\mathrm{G} \times \mathrm{P}$ & $\mathrm{P} \times \mathrm{D}$ & $\mathrm{G} \times \mathrm{D}$ & $\begin{array}{l}\mathrm{G} \times \mathrm{P} \\
\times \mathrm{D}\end{array}$ \\
\hline \multicolumn{17}{|l|}{ Rectal temperature, ${ }^{\circ} \mathrm{C}$} \\
\hline $1500 \mathrm{~h}$ & 38.43 & 38.64 & 38.49 & 38.47 & 38.30 & 38.40 & 40.15 & 40.56 & 0.12 & $<0.01$ & $<0.01$ & 0.01 & $<0.01$ & 0.34 & 0.82 & $\begin{array}{l}0.04 \\
0.29\end{array}$ \\
\hline $1800 \mathrm{~h}$ & 38.50 & 38.60 & 38.50 & 38.63 & 38.47 & 38.56 & 39.76 & 40.04 & 0.07 & $<0.01$ & $<0.01$ & $<0.01$ & $<0.01$ & 0.45 & 0.28 & 0.42 \\
\hline \multicolumn{17}{|l|}{$\mathrm{RR},{ }^{2}$ breaths/min } \\
\hline $0600 \mathrm{~h}$ & 39.5 & 39.8 & 38.6 & 40.6 & 37.4 & 37.4 & 64.5 & 73.7 & 1.6 & $<0.01$ & $<0.01$ & 0.02 & $<0.01$ & 0.16 & 0.02 & 0.11 \\
\hline $1500 \mathrm{~h}$ & 42.8 & 40.6 & 41.6 & 41.2 & 40.7 & 39.1 & 90.0 & 95.4 & 2.2 & $<0.01$ & $<0.01$ & 0.70 & $<0.01$ & 0.30 & 0.16 & 0.39 \\
\hline $1800 \mathrm{~h}$ & 38.8 & 39.9 & 38.4 & 40.3 & 38.1 & 37.7 & 81.2 & 89.3 & 1.7 & $<0.01$ & $<0.01$ & 0.02 & $<0.01$ & 0.32 & 0.05 & 0.12 \\
\hline \multirow{2}{*}{$\begin{array}{l}\text { Skin temperature, }{ }^{\circ} \mathrm{C} \\
0600 \mathrm{~h} \\
\mathrm{SR},{ }^{3} \mathrm{~g} / \mathrm{m}^{2} \text { per hour } \\
0600 \mathrm{~h}\end{array}$} & 32.09 & 32.10 & 31.45 & 31.55 & 31.39 & 31.32 & 34.93 & 34.90 & 0.22 & $<0.01$ & $<0.01$ & 0.84 & $<0.01$ & 0.72 & 0.82 & 0.94 \\
\hline & 24.90 & 24.93 & 26.85 & 29.52 & 16.92 & 16.10 & 27.94 & 28.84 & 1.70 & $<0.01$ & $<0.01$ & 0.46 & $<0.01$ & 0.59 & 0.37 & 0.85 \\
\hline
\end{tabular}

${ }^{1}$ During period 1, cows fed both diets (control, Con, or monensin, Mon) were housed in thermal neutral (TN) conditions and allowed to eat ad libitum. During period 2, cows fed both diets were either heat-stressed and allowed to eat ad libitum (HS) or pair-fed and kept in TN conditions (PFTN).

${ }^{2}$ Respiration rate.

${ }^{3}$ Sweating rate.

Table 3. Effects of diet (control or monensin) and environment (pair-feeding or heat stress) on production and metabolism variables in lactating Holstein cows ${ }^{1}$

\begin{tabular}{|c|c|c|c|c|c|c|c|c|c|c|c|c|c|c|c|c|}
\hline \multirow[b]{3}{*}{ Parameter } & \multicolumn{4}{|c|}{ Period (Per) 1} & \multicolumn{4}{|c|}{ Period 2} & \multirow[b]{3}{*}{ SEM } & \multirow{2}{*}{\multicolumn{7}{|c|}{$P$-value }} \\
\hline & \multicolumn{2}{|c|}{$\begin{array}{c}\text { Group (Grp) } 1 \\
\text { (TN) }\end{array}$} & \multicolumn{2}{|c|}{$\begin{array}{c}\text { Grp } 2 \\
(\mathrm{TN})\end{array}$} & \multicolumn{2}{|c|}{$\begin{array}{c}\text { Grp 1 } \\
\text { (PFTN) }\end{array}$} & \multicolumn{2}{|c|}{$\begin{array}{c}\text { Grp } 2 \\
(\mathrm{HS})\end{array}$} & & & & & & & & \\
\hline & Con & Mon & Con & Mon & Con & Mon & Con & Mon & & $\begin{array}{l}\text { Grp } \\
(\mathrm{G})\end{array}$ & Per $(\mathrm{P})$ & $\begin{array}{l}\text { Diet } \\
\text { (D) }\end{array}$ & $\mathrm{G} \times \mathrm{P}$ & $\mathrm{P} \times \mathrm{D}$ & $\mathrm{G} \times \mathrm{D}$ & $\begin{array}{c}\mathrm{G} \times \mathrm{P} \\
\times \mathrm{D}\end{array}$ \\
\hline $\mathrm{DMI}, \mathrm{kg} / \mathrm{d}$ & 19.81 & 18.53 & 21.52 & 20.90 & 15.70 & 13.52 & 17.34 & 15.07 & 0.78 & $<0.01$ & $<0.01$ & 0.01 & 0.69 & 0.25 & 0.79 & 0.73 \\
\hline DMI, $\%$ of BW & 3.77 & 3.58 & 3.91 & 3.77 & 3.09 & 2.69 & 3.20 & 2.79 & 0.12 & 0.05 & $<0.01$ & $<0.01$ & 0.69 & 0.14 & 0.88 & 0.87 \\
\hline Milk yield, $\mathrm{kg} / \mathrm{d}$ & 30.37 & 29.62 & 30.13 & 33.67 & 28.32 & 25.62 & 25.51 & 25.87 & 1.09 & 0.69 & $<0.01$ & 0.56 & 0.04 & 0.08 & 0.01 & 0.69 \\
\hline Milk yield, $\%$ of BW & 5.80 & 5.73 & 5.48 & 6.09 & 5.61 & 5.11 & 4.69 & 4.78 & 0.18 & 0.02 & $<0.01$ & 0.49 & 0.02 & 0.05 & 0.01 & 0.86 \\
\hline $\begin{array}{l}3.5 \% \text { FCM }, \mathrm{kg} / \mathrm{d} \\
\text { Milk components }\end{array}$ & 31.40 & 29.94 & 31.54 & 32.81 & 30.70 & 26.80 & 27.24 & 26.84 & 1.00 & 0.94 & $<0.01$ & 0.17 & 0.04 & 0.22 & 0.52 & 0.96 \\
\hline Fat, \% & 3.73 & 3.57 & 3.81 & 3.36 & 3.91 & 3.82 & 3.95 & 3.78 & 0.09 & 0.59 & 0.01 & $<0.01$ & 0.59 & 0.17 & 0.10 & 0.39 \\
\hline Protein, $\%$ & 2.70 & 2.58 & 2.72 & 2.66 & 2.56 & 2.48 & 2.63 & 2.51 & 0.05 & 0.18 & $<0.01$ & $<0.01$ & 0.97 & 0.94 & 0.91 & 0.51 \\
\hline Lactose, \% & 4.77 & 4.81 & 4.85 & 4.78 & 4.71 & 4.69 & 4.84 & 4.77 & 0.06 & 0.10 & 0.24 & 0.50 & 0.32 & 0.62 & 0.33 & 0.70 \\
\hline SNF, $\%$ & 8.41 & 8.35 & 8.48 & 8.37 & 8.24 & 8.07 & 8.37 & 8.18 & 0.10 & 0.25 & 0.01 & 0.02 & 0.59 & 0.55 & 0.80 & 0.95 \\
\hline $\mathrm{EBAL},{ }^{2} \mathrm{Mcal} / \mathrm{d}$ & 2.91 & 1.94 & 5.16 & 3.21 & -2.31 & -3.68 & -0.80 & -4.06 & 0.73 & 0.01 & $<0.01$ & $<0.01$ & 0.25 & 0.41 & 0.17 & 0.67 \\
\hline Feed efficiency ${ }^{3}$ & 1.61 & 1.63 & 1.47 & 1.60 & 1.95 & 2.03 & 1.59 & 1.81 & 0.05 & $<0.01$ & $<0.01$ & $<0.01$ & $<0.01$ & 0.24 & 0.06 & 0.75 \\
\hline
\end{tabular}




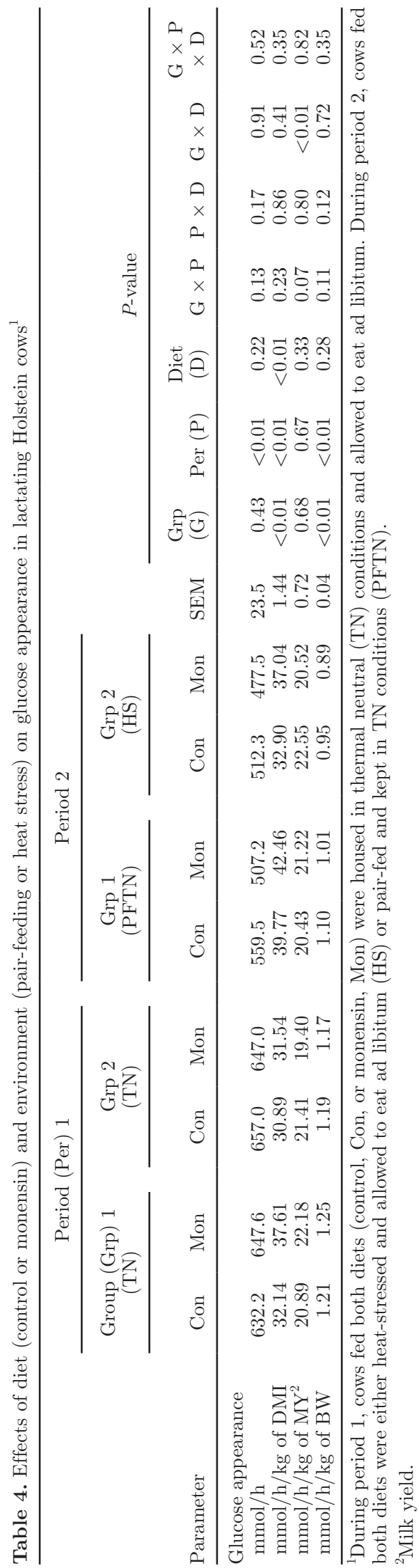

for both PFTN and HS cows. The negative EBAL nadir $(-4.56$ Mcal) occurred on d 4 of P2 for both PFTN and HS cows (data not shown). Overall, group 2 cows had a greater $(P<0.01)$ calculated EBAL than group 1 cows $(-0.28$ vs. $0.88 \mathrm{Mcal} / \mathrm{d}$; Table 3$)$, but this difference existed in P1 and continued during P2. Overall, cows fed monensin had a lower calculated EBAL compared with control-fed cows (1.24 vs. $-0.65 \mathrm{Mcal} / \mathrm{d}$; Table $3)$ and increased $(P<0.01)$ feed efficiency $(1.65$ vs. 1.77; Table 3). A group by period interaction $(P<$ 0.01 ) occurred as efficiency increased more (0.33 units) during P2 in PFTN cows than it did (0.17 units) during $\mathrm{P} 2$ in HS cows (Table 3 ). During P2, both groups lost $(P<0.01)$ BW, but PFTN cows lost more $(P<0.01)$ than HS cows ( -32.4 vs. $-16.7 \mathrm{~kg}$; data not shown). Monensin had no effect on BW loss.

Total glucose Ra decreased $(P<0.01)$ from $\mathrm{P} 1$ to P2 (646 vs. $514 \mathrm{mmol} / \mathrm{h}$ ), but was unaffected by group or diet (Table 4; Figure 1). Overall, group 1 cows produced more $(P<0.01)$ glucose per unit of DMI than group 2 cows ( 38 vs. $33 \mathrm{mmol} / \mathrm{h}$ per $\mathrm{kg}$ of DMI), but this difference existed in P1 and continued during P2 (Table 4). Compared with that in P1, glucose Ra on a DMI basis increased $(15 \% ; P<0.01)$ during P2 (Table 4). Compared with control-fed cows, monensin-fed cows had an overall greater $(P<0.01)$ glucose Ra on a DMI basis (34 vs. $37 \mathrm{mmol} / \mathrm{h}$ per $\mathrm{kg}$ of DMI; Table 4; Figure 2). No significant main effects were found on glucose Ra per unit of milk yield (Table 4), but a group by period interaction $(P=0.07)$ tended to occur as glucose Ra per unit of milk yield decreased in PFTN cows from P1 to $\mathrm{P} 2$ (21.5 vs. $20.8 \mathrm{mmol} / \mathrm{h}$ per $\mathrm{kg}$ of milk) but increased in HS cows from P1 to P2 (20.4 vs. $21.5 \mathrm{mmol} / \mathrm{h}$ per $\mathrm{kg}$ of milk; Table 4$)$. On a BW basis, PFTN cows produced more $(P<0.01)$ glucose than HS cows (1.14 vs. $1.05 \mathrm{mmol} / \mathrm{h}$ per $\mathrm{kg}$ of BW), but this difference existed in P1 and remained in P2 (Table 4). Overall glucose Ra on a BW basis decreased $(P<0.01)$ in P2 compared with $\mathrm{P} 1$ (1.21 vs. $0.99 \mathrm{mmol} / \mathrm{h}$ per $\mathrm{kg}$ of BW; Table 4).

A group by period interaction $(P<0.01)$ was observed for basal plasma glucose levels as glucose content did not change from $\mathrm{P} 1$ to $\mathrm{P} 2$ in PFTN cows $(67.8$ vs. $68.1 \mathrm{mg} / \mathrm{dL}$; Table 5), but decreased from P1 to P2 in HS cows (67.7 vs. $64.6 \mathrm{mg} / \mathrm{dL})$. Monensin had no overall effect on daily plasma glucose content (Table 5). Overall and compared with control-fed cows, monensinfed cows had a slight increase $(P<0.01)$ in basal NEFA levels (103 vs. $123 \mu \mathrm{Eq} / \mathrm{L}$; Table 5 ). A group by period interaction $(P<0.01)$ was observed as basal NEFA decreased in group 1 cows during P2 (120 vs. $111 \mu \mathrm{Eq} / \mathrm{L})$ but increased slightly in group 2 cows during P2 (106 vs. $117 \mu \mathrm{Eq} / \mathrm{L}$; Table 5). A period by diet interaction $(P<0.01)$ was also found as control-fed cows had a 


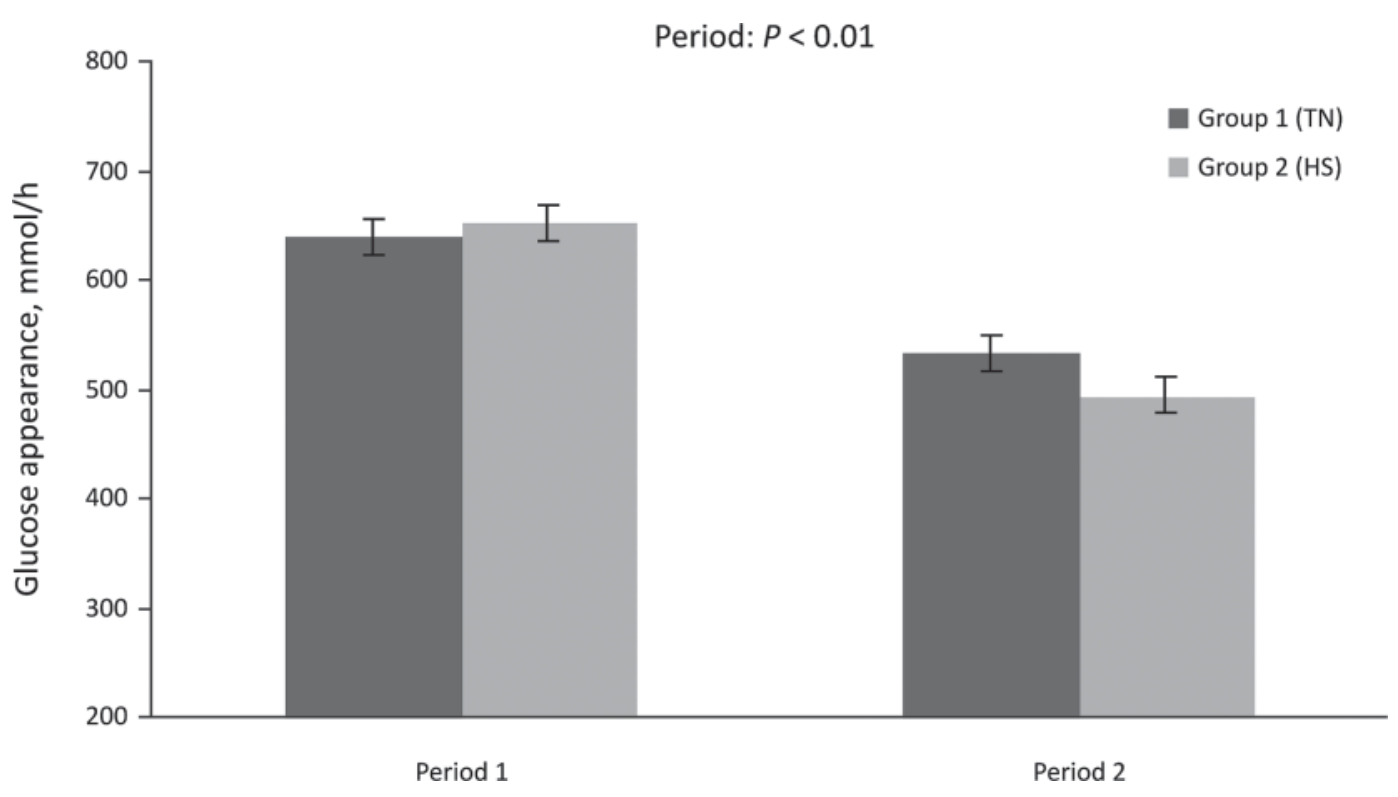

Figure 1. Effects of period (P) and group (1 or 2) on whole-animal glucose rate of appearance in lactating Holstein cows. During P1, all cows were housed in thermal neutral (TN) conditions and allowed to eat ad libitum. During P2, cows were exposed to heat stress (HS, group 2 ) or exposed to TN conditions and pair-fed (group 1) with the HS cows.

small decrease in blood NEFA levels from P1 to P2 (110 vs. $96 \mu \mathrm{Eq} / \mathrm{L}$ ), but monensin-fed cows had a slight increase (115 vs. $132 \mu \mathrm{Eq} / \mathrm{L}$; Table 5). A trend was observed for a group by period interaction $(P=0.07)$ on PUN as levels remained similar in PFTN cows from P1 to P2, but PUN content increased $(\sim 10 \%)$ from P1 to P2 in HS cows (Table 5). No main or interaction effects were found for basal insulin levels or the glucose:insulin ratio (Table 5).

The glucose response (AUC) to the epinephrine challenge was greater $(P<0.01)$ in $\mathrm{P} 2$ compared with $\mathrm{P} 1$ (1,759 vs. $2,230 \mathrm{mg} / \mathrm{dL} \cdot \mathrm{min})$, but was unaffected by group or diet (Table 6). A trend was observed for a group by period interaction $(P=0.08$; Table 6$)$ on the lipolytic response to the epinephrine challenge as the increase in NEFA from P1 to P2 was larger (3,446 vs. $6,725 \mu \mathrm{Eq} / \mathrm{L} \cdot \mathrm{min})$ in PFTN cows compared with HS cows $(2,714$ vs. $4,301 \mu \mathrm{Eq} / \mathrm{L} \cdot \mathrm{min}$; Figure 3$)$.

A trend $(P=0.09)$ was detected for a group by period interaction on glucose disposal following the GTT as glucose AUC increased more from P1 to P2 in HS cows (from 2,643 to $3,607 \mathrm{mg} / \mathrm{dL} \cdot \mathrm{min}$ ) than in PFTN cows (from 2,673 to $3,240 \mathrm{mg} / \mathrm{dL} \cdot \mathrm{min}$; Table 6). Compared with control-fed cows, monensin-fed cows tended

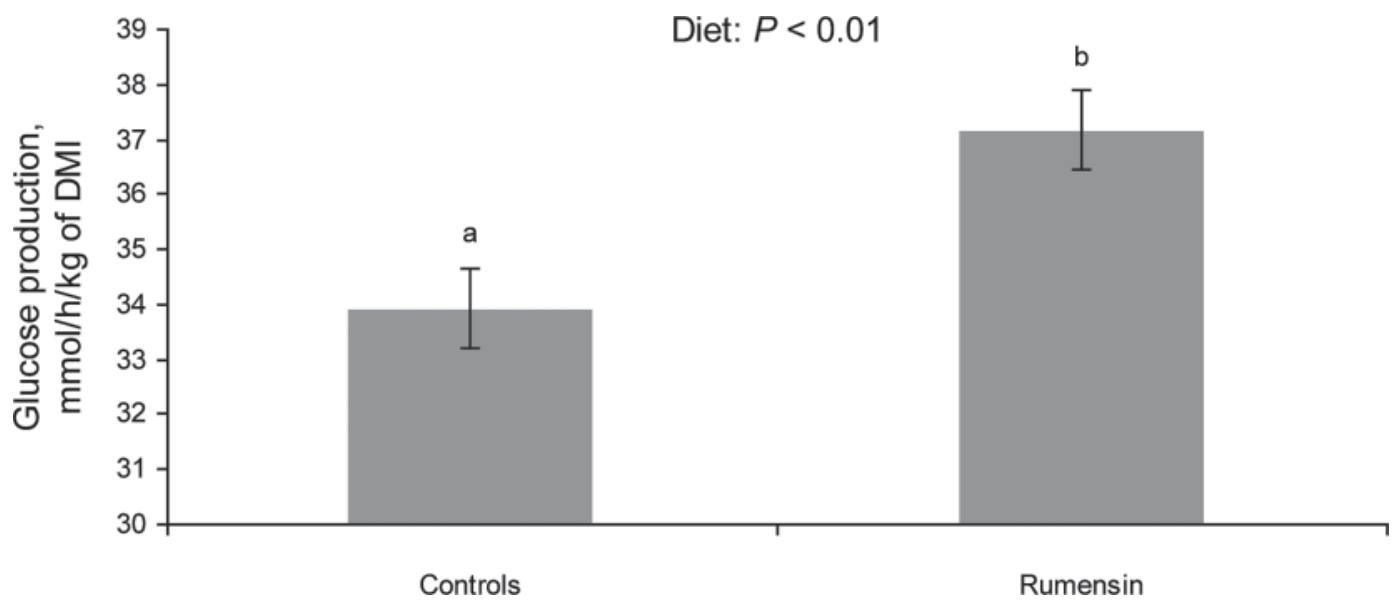

Figure 2. Effects of diet (control or monensin) on whole-body glucose production per unit of DMI in lactating Holstein cows. Bars with different letters $(\mathrm{a}, \mathrm{b})$ differ at $P<0.01$. 


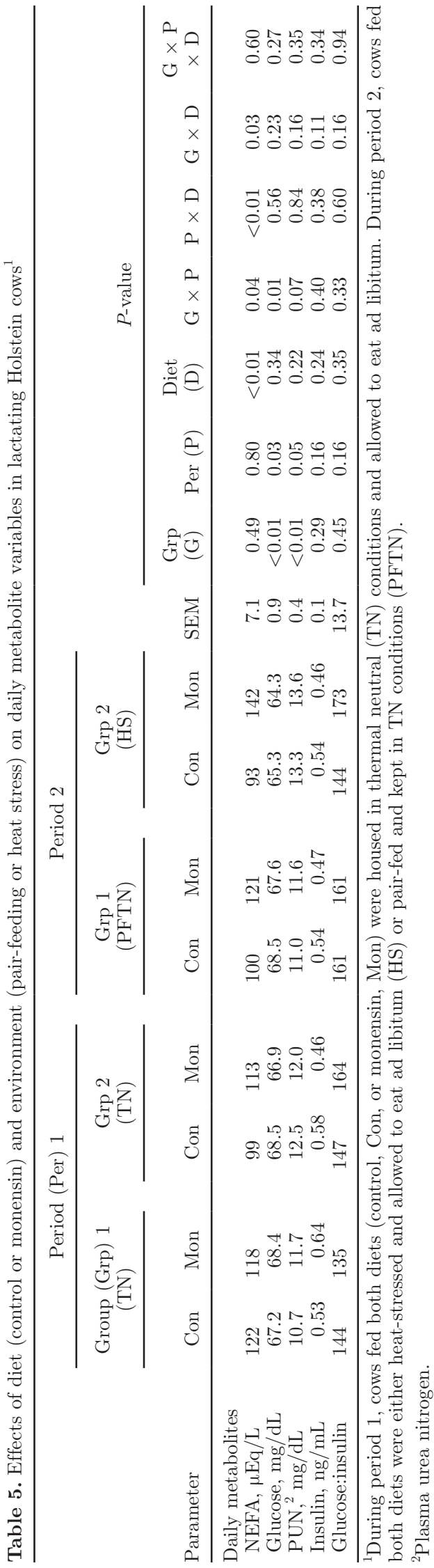

$(P=0.05)$ to have a reduced ability to dispose of blood glucose following the GTT (2,927 vs. $3,156 \mathrm{mg} / \mathrm{dL} \cdot \mathrm{min}$; Table 6). A group by period interaction $(P=0.03)$ was observed on the insulin response to the GTT as the response decreased during P2 in PFTN cows (165 vs. $119 \mathrm{ng} / \mathrm{mL} \cdot \mathrm{min})$, but remained similar in HS cows during P2 (Table 6; Figure 4). The glucose:insulin ratio during the GTT was increased $(P<0.01)$ during P2 compared with P1 (20.9 vs. 29.9; Table 6 ), but was unaffected by diet or group.

\section{DISCUSSION}

Utilizing the pair-feeding experimental design enabled us to evaluate thermal stress while eliminating the confounding effects of dissimilar nutrient intake between thermal neutral and heat stress conditions. This model also allowed us to evaluate bioenergetic variables, which are sensitive to small differences in energy intake.

Exposing cows to an environmental heat load well above the bovine thermal comfort zone resulted in a marked increase of all body temperature variables measured (all of which were characteristic of extreme hyperthermia). In fact, HS cows still exhibited elevated rectal temperatures $\left(0.92^{\circ} \mathrm{C}\right)$ and increased respiration rate (31 breaths/min) at $0600 \mathrm{~h}$, indicating that heat strain was maintained for the entire $24 \mathrm{~h}$ of each day. Interestingly, monensin-fed cows had a slight increase in rectal temperature even during $\mathrm{TN}$ conditions $\left(0.18^{\circ} \mathrm{C}\right)$ and in respiration rates during the morning and evening of HS conditions. This is surprising because monensin-fed cows produced similar amounts of milk (milk synthesis is proportional to metabolic heat production) but had reduced feed intake and thus presumably had less overall digestion-induced heat production. Regardless, understanding why monensin-fed cows had a slightly elevated rectal temperature and whether this is biologically significant is of interest.

Thermal stress caused an immediate and precipitous decrease in DMI, and the temporal pattern and magnitude of decrease $(\sim 28 \%)$ closely resembles that of our previous experiments (Rhoads et al., 2009; Shwartz et al., 2009; Wheelock et al., 2010). By design, the PFTN cows had a parallel pattern of reduced nutrient intake. Compared with controls, monensin-fed cows had a similar reduction in feed intake during $\mathrm{P} 2$, but consumed less feed overall $(\sim 1.6 \mathrm{~kg})$ than controls and this was expected because decreased nutrient intake is a welldocumented monensin effect in growing and lactating ruminants (Schelling, 1984; Ipharraguerre and Clark, 2003).

The heat load markedly reduced milk yield (33\%), and the decrease in the HS cows was more than twice 
Table 6. Effects of diet (control or monensin) and environment (pair-feeding or heat stress) on metabolite variables in response to an epinephrine (EPI) challenge and glucose tolerance test (GTT) in lactating Holstein cows $^{1}$

\begin{tabular}{|c|c|c|c|c|c|c|c|c|c|c|c|c|c|c|c|c|}
\hline \multirow[b]{3}{*}{ Parameter } & \multicolumn{4}{|c|}{ Period (Per) 1} & \multicolumn{4}{|c|}{ Period 2} & \multirow[b]{3}{*}{ SEM } & \multirow{2}{*}{\multicolumn{7}{|c|}{$P$-value }} \\
\hline & \multicolumn{2}{|c|}{$\begin{array}{c}\text { Group (Grp) } 1 \\
\text { (TN) }\end{array}$} & \multicolumn{2}{|c|}{$\begin{array}{l}\text { Grp } 2 \\
(\mathrm{TN})\end{array}$} & \multicolumn{2}{|c|}{$\begin{array}{c}\text { Grp 1 } \\
(\text { PFTN) }\end{array}$} & \multicolumn{2}{|c|}{$\begin{array}{c}\text { Grp } 2 \\
\text { (HS) }\end{array}$} & & & & & & & & \\
\hline & Con & Mon & Con & Mon & Con & Mon & Con & Mon & & $\begin{array}{l}\text { Grp } \\
(G)\end{array}$ & Per $(\mathrm{P})$ & $\begin{array}{l}\text { Diet } \\
\text { (D) }\end{array}$ & $\mathrm{G} \times \mathrm{P}$ & $\mathrm{P} \times \mathrm{D}$ & $G \times D$ & $\begin{array}{l}\mathrm{G} \times \mathrm{P} \\
\times \mathrm{D}\end{array}$ \\
\hline \multicolumn{17}{|l|}{ EPI challenge } \\
\hline $\begin{array}{l}\text { Glucose response } \\
\text { AUC }^{2}\end{array}$ & 1,842 & 1,688 & 1,721 & 1,783 & 2,328 & 2,478 & 2,069 & 2,045 & 223 & 0.25 & $<0.01$ & 0.96 & 0.29 & 0.73 & 0.95 & 0.54 \\
\hline $\begin{array}{l}\text { NEFA response } \\
\text { AUC }^{3} \\
\text { GTT }\end{array}$ & 3,328 & 3,566 & 2,461 & 2,968 & 6,366 & 7,084 & 3,889 & 4,715 & 694 & $<0.01$ & $<0.01$ & 0.24 & 0.08 & 0.68 & 0.85 & 0.93 \\
\hline $\begin{array}{l}\text { GII } \\
\text { Glucose response }\end{array}$ & & & & & & & & & & & & & & & & \\
\hline $\begin{array}{l}\mathrm{AUC}^{4} \\
\text { Insulin response }\end{array}$ & 2,548 & 2,799 & 2,578 & 2,710 & 3,067 & 3,414 & 3,514 & 3,701 & 165 & 0.15 & $<0.01$ & 0.05 & 0.09 & 0.75 & 0.55 & 0.93 \\
\hline $\mathrm{AUC}^{5}$ & 159.0 & 172.0 & 146.5 & 145.1 & 121.9 & 116.2 & 151.2 & 179.6 & 21.8 & 0.38 & 0.38 & 0.58 & 0.03 & 0.86 & 0.75 & 0.43 \\
\hline Glucose:insulin & 18.5 & 21.0 & 19.2 & 24.9 & 33.0 & 32.9 & 29.3 & 24.4 & 5.3 & 0.61 & 0.01 & 0.83 & 0.27 & 0.39 & 0.92 & 0.59 \\
\hline
\end{tabular}

${ }^{1}$ During period 1, cows fed both diets (control, Con, or monensin, Mon) were housed in thermal neutral (TN) conditions and allowed to eat ad libitum. During period 2, cows fed both diets were either heat-stressed and allowed to eat ad libitum (HS) or pair-fed and kept in TN conditions (PFTN).

both diets were either heat-stressed and allowed to eat ad libitum (HS) or pair-
${ }^{2}$ Area under the curve $(\mathrm{mg} / \mathrm{dL} \cdot \mathrm{min})$ at $90 \mathrm{~min}$ post-epinephrine administration.

¿ ${ }^{3}$ Area under the curve $(\mu \mathrm{Eq} / \mathrm{L} \cdot \mathrm{min})$ at $45 \mathrm{~min}$ post-epinephrine administration.

D. ${ }^{4}$ Area under the curve $(\mathrm{mg} / \mathrm{dL} \cdot \mathrm{min})$ at $60 \mathrm{~min}$ post-glucose administration.

음 ${ }^{5}$ Area under the curve $(\mathrm{mg} / \mathrm{dL} \cdot \mathrm{min})$ at $45 \mathrm{~min}$ post-glucose administration. 


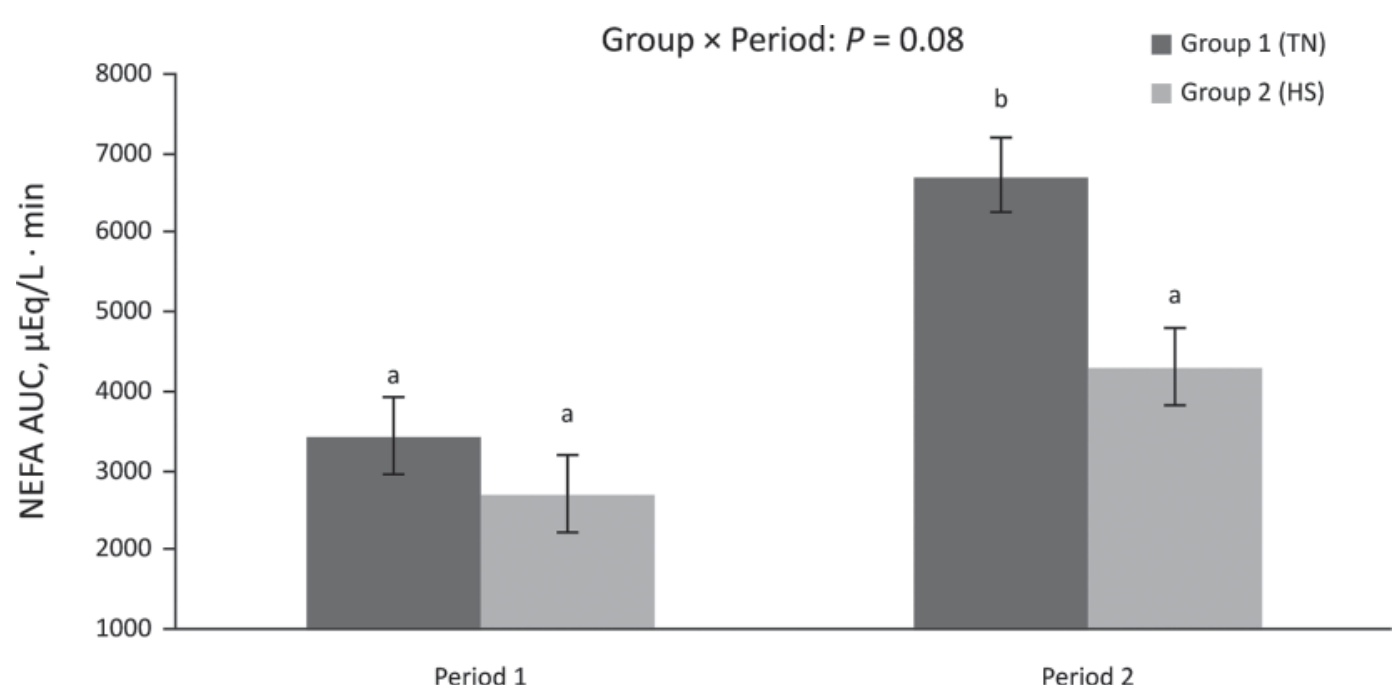

Figure 3. Effects of period (P) and group (1 or 2) on NEFA response (area under the curve; AUC) to the epinephrine challenge in lactating Holstein cows. During P1, all cows were housed in thermal neutral (TN) conditions and allowed to eat ad libitum. During P2, cows were exposed to heat stress (HS, group 2) or exposed to TN conditions and pair-fed (group 1) with the HS cows. Bars with different letters (a, b) differ at $P<0.10$.

that of the PFTN group (9.09 vs. $4.46 \mathrm{~kg}$ ), despite both having similar reductions in nutrient intake. This indicates that approximately $50 \%$ of the decrease in heat-induced milk production is caused by reduced feed intake and this value is consistent with our previous results supporting the reproducibility of this model system (Rhoads et al., 2009; Wheelock et al., 2010). Feeding monensin did not ameliorate or prevent the decrease in heat-induced milk yield as we had hypothesized.
Both PFTN and HS cows entered negative EBAL (averaged -2.71 Mcal/d) during P2 (the temporal pattern closely resembles the reduced DMI) and nadir occurred on d 4 (-4.56 Mcal), which agrees with our previous results (Shwartz et al., 2009; Wheelock et al., 2010). The loss of BW (24.5 kg) supports the EBAL calculations, but the proportion of reduced BW due to decreased gut fill (because of reduced feed intake) is not clear. Compared with controls, monensin-fed cows had an overall reduced calculated EBAL (1.89 Mcal),

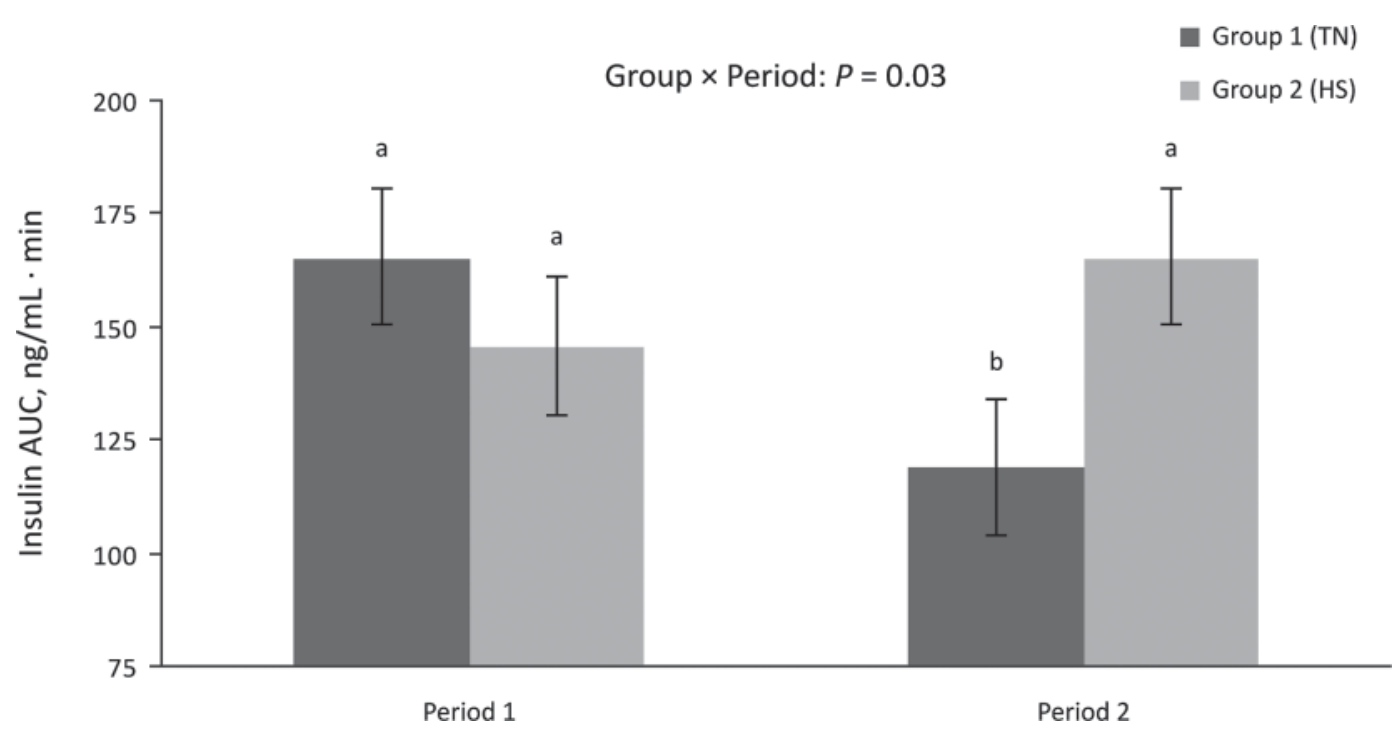

Figure 4. Effects of period (P) and group (1 or 2) on the insulin response (area under the curve; AUC) to the glucose tolerance test in lactating Holstein cows. During P1, all cows were housed in thermal neutral (TN) conditions and allowed to eat ad libitum. During P2, cows were exposed to heat stress (HS, group 2) or exposed to TN conditions and pair-fed (group 1) with the HS cows. Bars with different letters (a, b) differ at $P<0.05$. 
which was due to the reduced DMI, as milk yield did not differ between diets. However, EBAL is probably underestimated in monensin-fed cows because the beneficial effects of monensin on digestibility energetics are currently not incorporated into the NRC (2001) EBAL equations. Furthermore, BW loss was similar between controls and monensin-fed cows, suggesting that actual EBAL was similar between diets.

Overall environment or diet did not affect milk lactose content. However, due to the difference in milk production during $\mathrm{P} 2$, milk lactose yield in $\mathrm{HS}$ and PFTN cows (d 7-9) decreased by 436 and $209 \mathrm{~g} / \mathrm{d}$, respectively. Thus, HS cows secreted $227 \mathrm{~g}$ less lactose/d or about $238 \mathrm{~g}$ less glucose/d, which agrees with our previous research (Rhoads et al., 2009; Wheelock et al., 2010). Similar calculations can be made on milk fat and protein differentials, but based upon our previous bioenergetic findings (Rhoads et al., 2009, 2011; O'Brien et al., 2010; Wheelock et al., 2010), we believe the differential in milk lactose synthesis is a mechanistic clue as to why HS decreases milk yield independently of nutrient intake.

The majority of dietary carbohydrates are fermented in the rumen, thus the lactating cow relies heavily upon gluconeogenesis (primarily from the liver) to satisfy its glucose requirement. Rumen-derived propionate is the largest contributor $(\sim 50 \%)$, whereas lactate and amino acids supply roughly $15 \%$ each of the carbon for glucose production (Huntington, 1990). The contributions of glycerol and amino acids (from adipose and lean tissue, respectively) markedly increase during periods of inadequate feed intake (i.e., negative EBAL; Bell, 1995). This experiment used stable isotopically labeled glucose and tracer kinetic methodologies to measure whole-body glucose appearance; however, this method is a proxy for hepatic gluconeogenesis because the diet and kidney are negligible sources of glucose in ruminants (Huntington, 1990). In the current study, overall whole-body glucose Ra decreased during P2 and was not affected by diet nor influenced by PFTN or HS conditions. The decrease in glucose Ra was not as severe as the decrease in feed intake (20 vs. $28 \%$ ), which suggests that precursors besides propionate increased their carbon contribution to gluconeogenesis. This observation is consistent with the reported increase in gene expression of hepatic pyruvate carboxylase during HS and the increased ability of the liver to shuttle lactate and alanine into the gluconeogenesis pathway (Rhoads et al., 2011). Compared with cows in P1, cows in both HS $(12 \%)$ and PFTN (18\%) conditions had increased glucose Ra when evaluated on a DMI basis. This increase also suggests that amino acids and other non-propionate precursors contributed more to glucose production during P2. Monensin-fed cows also produced more $(\sim 10 \%)$ glucose per unit of feed intake than controls, which was anticipated because monensin alters rumen fermentation, as characterized by increased propionate production and reduced methane synthesis (Schelling, 1984; Ipharraguerre and Clark, 2003). Glucose Ra per unit of milk yield decreased $(3.3 \%)$ in PFTN cows during P2, but increased $(5.6 \%)$ in HS cows. This is consistent with our other preliminary data, which suggested that glucose is being preferentially utilized for processes other than milk synthesis (ostensibly by insulin-responsive tissues) during heat stress. In further support, coupling the fact that total glucose Ra was similar between PFTN and HS cows during P2 with the milk lactose yield differential suggests that extramammary tissues utilize $\sim 225$ g glucose/d more under HS than under PFTN conditions.

Heat-stressed cows were hypoglycemic, whereas blood glucose content in the PFTN controls did not change during P2. The reduced glucose levels in heatstressed cows are in agreement with studies using heatstressed rats (Mitev et al., 2005), chickens (Rahimi, 2005), sheep (Achmadi et al., 1993), and heifers and cows (Nardone et al., 1997; Itoh et al., 1998; Ronchi et al., 1999; Abeni et al., 2007; Shwartz et al., 2009). The fact that PFTN cows did not also have a reduction in blood glucose is in contrast to our previous lactation trials, where both HS and PFTN cows had a reduction in basal blood glucose levels (Rhoads et al., 2009; Wheelock et al., 2010). In other nonruminant species, a heat-load actually induces an increase in blood glucose (chickens, Bobek et al., 1997; Garriga et al., 2006; rabbits, Marder et al., 1990; sows, Prunier et al., 1997; and exercising men, Fink et al., 1975; Febbraio, 2001). For example, HS athletes consistently have increased hepatic glucose production and whole-body enhanced carbohydrate oxidation at the expense of lipids (Fink et al., 1975; Febbraio, 2001; Jentjens et al., 2002). In addition, hepatic glucose export typically decreases after carbohydrates are ingested, but exogenous sugars are unable to blunt the HS-induced liver glucose output (Angus et al., 2001). The increased hepatic glucose output originates from both increased glycogenolysis (Febbraio, 2001) and increased gluconeogenesis (Collins et al., 1980). Furthermore, HS chicks show increased intestinal $\mathrm{Na}^{+}$/glucose cotransporter (SGLT-I) activity and thus glucose uptake (Garriga et al., 2006), and in vitro experiments indicate an enhanced renal glucose reabsorptive capacity (via SGLT-I) during a thermal load (Sussman and Renfro, 1997; Ikari et al., 2005). Collectively, the evidence suggests that many of these changes occur to maximize glucose availability in an effort to preferentially oxidize carbohydrates. Reasons for the discrepancies between studies are not clear, but species differences, altered physiological states (lacta- 
tion vs. growth), extent and length of hyperthermia, and diet all likely contribute to the variation observed in circulating glucose levels.

To gain a better appreciation for the changes in postabsorptive carbohydrate and lipid metabolism, we administered a GTT and an EPI challenge. Both HS and PFTN cows had a reduced ability (compared with cows in P1) to dispose of blood glucose following the GTT; in fact, HS cows tended to have a larger AUC than PF cows. This contradicts rodent data (Kokura et al., 2007) and our previous lactation trial that indicated a more rapid glucose clearance during HS (Wheelock et al., 2010). Seemingly, this also appears to contradict the glucose "accounting" (described above), which suggests an increase in glucose utilization by extra-mammary tissues during heat stress. A possible explanation may be reduced glucose uptake $(\sim 225 \mathrm{~g} / \mathrm{d})$ into mammary tissue (a non-insulin-sensitive tissue, at least from a glucose uptake perspective), which complicates the interpretation of glucose disposal. Regardless, reasons why HS cows in the current study not only did not have improved but actually had impaired glucose clearance is currently not fully understood. The pancreas recognizes glucose and responds by secreting insulin; in agreement with our lactation and growth data (O'Brien et al., 2010; Wheelock et al., 2010), HS cows in the current study had a similar insulin response during P2, whereas the PFTN controls had a reduced insulin response to the GTT. Compared with PFTN cows, HS cows had a larger insulin response to the GTT, which also agrees with data from heat-stressed sheep (Achmadi et al., 1993). The quick timing (within $10 \mathrm{~min}$ ) suggests that this is because of pancreatic secretion rather than insulin removal (by insulin-sensitive tissues).

The EPI challenge causes immediate adipose tissue triglyceride lipolysis (increased blood NEFA) and hepatic glycogen breakdown (increased blood glucose), and the response to this homeostatic molecule can be used as a proxy for tissue sensitivity to catabolic signals. Both PFTN and HS cows had a similar increase in blood glucose following EPI administration during P2, suggesting that the liver remains equally sensitive (with regard to breaking down glycogen and releasing glucose) to EPI. The maintenance of glycogenolytic sensitivity to EPI during HS coupled with similar (to PFTN cows) rates of glucose appearance suggest that the liver remains functional with regards to glucose export during HS. In contrast, the NEFA response to the EPI challenge was much larger $(56 \%)$ in the PFTN controls compared with the HS cows during P2, suggesting that adipose tissue becomes refractory to lipolytic stimulation during HS. The increased pancreatic responsiveness to glucose (with regards to insulin secretion) may help explain why epinephrine is less ef- fective at stimulating adipose breakdown during HS, as insulin is a potent antilipolytic signal (Vernon, 1992). Regardless, the differential sensitivity to an adrenergic hormone between the liver and adipose tissue during P2 supports our hypothesis that HS cows are attempting to minimize NEFA and maximize glucose entry into the circulating energetic pool.

\section{CONCLUSIONS}

Similar to our previous results, the current research demonstrated that the heat stress-induced decrease in DMI only accounts for approximately $50 \%$ of the reduction in milk yield. Changes in postabsorptive metabolism may account for a large portion of the remainder of milk loss. Specifically, hepatic glucose production in HS cows is similar to that in thermal neutral cows on a similar plane of nutrition. However, heat-stressed cows fail to enlist glucose "sparing" mechanisms (adipose mobilization, which normally prevents severe reductions in milk yield during periods of inadequate nutrient intake) and consequently the contribution of glucose to whole-body energetics increases. This failure to spare glucose causes redistribution to the hierarchy of glucose-utilizing tissues, with the mammary gland assuming reduced importance on the priority list.

\section{ACKNOWLEDGMENTS}

The authors express their appreciation to Rosemarie Burgos-Zimbleman, Gilad Shwartz, Octavio Mendivil, Sarah Hartman, and Jennifer Ernest for assistance at the University of Arizona's Agriculture Research Complex. The technical assistance of Dairy Nutrition Services (Chandler, AZ) was greatly appreciated.

\section{REFERENCES}

Abeni, F., L. Calamari, and L. Stefanini. 2007. Metabolic conditions of lactating Friesian cows during the hot season in the Po valley. 1. Blood indicators of heat stress. Int. J. Biometeorol. 52:87-96.

Achmadi, J., T. Yanagisawa, H. Sano, and Y. Terashima. 1993. Pancreatic insulin secretory response and insulin action in heat-exposed sheep given a concentrate or roughage diet. Domest. Anim. Endocrinol. 10:279-287.

Angus, D. J., M. A. Febbraio, D. Lasini, and M. Hargreaves. 2001. Effect of carbohydrate ingestion on glucose kinetics during exercise in the heat. J. Appl. Physiol. 90:601-605.

AOAC. 2000. Official Methods of Analysis. 17th ed. AOAC International, Arlington, VA.

Baumgard, L. H., W. J. Weber, H. Chester-Jones, L. B. Hansen, G. W. Kazmer, S. A. Zinn, and B. A. Crooker. 2002. Growth hormone response to growth hormone releasing factor by Holstein calves from genetic lines selected for milk yield. J. Dairy Sci. 85:2529-2540.

Beede, D. K., and R. J. Collier. 1986. Potential nutritional strategies for intensively managed cattle during thermal stress. J. Anim. Sci. 62:543-554

Bell, A. W. 1995. Regulation of organic nutrient metabolism during transition from late pregnancy to early lactation. J. Anim. Sci. 73:2804-2819. 
Bernabucci, U., N. Lacetera, L. H. Baumgard, R. P. Rhoads, B. Ronchi, and A. Nardone. 2010. Metabolic and hormonal adaptations to heat stress in ruminants. Animal 4:1167-1183.

Bobek, S., A. Sechman, E. Wieczorek, D. Wronska-Fortuna, K. Koziec, and J. Niezgoda. 1997. Reverse 3,3',5'-triiodothyronine (rT3) enhances hyperglycemia and lipemic effects of heat-stress in chickens. Horm. Metab. Res. 29:252-254.

Burgos, R., L. J. Odens, R. J. Collier, L. H. Baumgard, and M. J. VanBaale. 2007. Evaluation of different cooling systems in lactating heat stressed dairy cows in a semi-arid environment. Prof. Anim. Sci. 23:546-555.

Collier, R. J., D. K. Beede, W. W. Thatcher, L. A. Israel, and C. J. Wilcox. 1982. Influences of environment and its modification on dairy animal health and production. J. Dairy Sci. 65:2213-2227.

Collins, F. G., F. A. Matros, and J. L. Skibba. 1980. Effect of palmitate on hepatic biosynthetic functions at hyperthermic temperatures. Metabolism 29:524-531.

Febbraio, M. A. 2001. Alterations in energy metabolism during exercise and heat stress. Sports Med. 31:47-59.

Fink, W. J., D. L. Costill, and P. J. Van Handel. 1975. Leg muscle metabolism during exercise in the heat and cold. Eur. J. Appl. Physiol. Occup. Physiol. 34:183-190.

Fuquay, J. W. 1981. Heat stress as it affects production. J. Anim. Sci. $52: 164-174$.

Garriga, C., R. R. Hunter, C. Amat, J. M. Planas, M. A. Mitchell, and M. Moreto. 2006. Heat stress increases apical glucose transport in the chicken jejunum. Am. J. Physiol. Regul. Integr. Comp. Physiol. 290:R195-R201.

Huntington, G. B. 1990. Energy metabolism in the digestive track and liver of cattle: Influence of physiological state and nutrition. Reprod. Nutr. Dev. 30:35-47.

Ikari, A., M. Nakano, Y. Suketa, H. Harada, and K. Takagi. 2005. Reorganization of ZO-I by sodium-dependent glucose transporter activation after heat stress in LLC-PK1 cells. J. Cell. Physiol. 203:471-478.

Ipharraguerre, I. R., and J. H. Clark. 2003. Usefulness of ionophores for lactating dairy cows: A review. Anim. Feed Sci. Technol. 106:39-57.

Itoh, F., Y. Obara, M. T. Rose, H. Fuse, and H. Hashimoto. 1998. Insulin and glucagon secretion in lactating cows during heat exposure. J. Anim. Sci. 76:2182-2189.

Jentjens, R. L. P. G., A. J. M. Wagenmakers, and A. E. Jeukendrup. 2002. Heat stress increases muscle glycogen use but reduces the oxidation of ingested carbohydrates during exercise. J. Appl. Physiol. 92:1562-1572.

Kokura, S., S. Adachi, E. Manabe, K. Mizushima, T. Hattori, T. Okuda, N. Nakabe, O. Handa, T. Takagi, Y. Naito, N. Yoshida, and T. Yoshikawa. 2007. Whole body hyperthermia improves obesityinduced insulin resistance in diabetic mice. Int. J. Hyperthermia 23:259-265.

Marder, J., U. Eylath, E. Moskovitz, and R. Sharir. 1990. The effect of heat exposure on blood chemistry of the hyperthermic rabbit. Comp. Biochem. Physiol. A Comp. Physiol. 97:245-247.

Mitev, S., S. Dinevska-Kovkarovska, and B. Miova. 2005. Effect of the acclimation to high environmental temperature on the activity of hepatic glycogen phosphorylase $(\mathrm{a}+\mathrm{b}$ and $\mathrm{a})$, liver glycogen content and blood glucose level in rat. J. Therm. Biol. 30:563-568.

Nardone, A., N. Lacetera, U. Bernabucci, and B. Ronchi. 1997. Composition of colostrum from dairy heifers exposed to high air temperatures during late pregnancy and the early postpartum period. J. Dairy Sci. 80:838-844.
National Research Council. 1989. Nutrient Requirements of Dairy Cattle, 6th rev. ed. Nat. Acad. Press, Washington, DC.

National Research Council. 2001. Nutrient Requirements of Dairy Cattle, 7th rev. ed. Nat. Acad. Press, Washington, DC.

O'Brien, M. D., R. P. Rhoads, S. R. Sanders, G. C. Duff, and L. H. Baumgard. 2010. Metabolic adaptations to heat stress in growing cattle. Domest. Anim. Endocrinol. 38:86-94.

Prunier, A., M. Messias de Braganca, and J. L. Dividich. 1997. Influence of high ambient temperature on performance of reproductive sows. Livest. Prod. Sci. 52:123-133.

Rahimi, G. 2005. Effect of heat shock at early growth phase on glucose and calcium regulating axis in broiler chickens. Int. J. Poult. Sci. 4:790-794.

Rhoads, M. L., J. W. Kim, R. J. Collier, B. A. Crooker, Y. R. Boisclair, L. H. Baumgard, and R. P. Rhoads. 2010. Effects of heat stress and nutrition on lactating holstein cows: II. Aspects of hepatic growth hormone responsiveness. J. Dairy Sci. 93:170-179.

Rhoads, M. L., R. P. Rhoads, M. J. VanBaale, R. J. Collier, S. R. Sanders, W. J. Weber, B. A. Crooker, and L. H. Baumgard. 2009. Effects of heat stress and plane of nutrition on lactating Holstein cows: I. Production, metabolism and aspects of circulating somatotropin. J. Dairy Sci. 92:1986-1997.

Rhoads, R. P., A. J. La Noce, J. B. Wheelock, and L. H. Baumgard. 2011. Short communication: Alterations in expression of gluconeogenic genes during heat stress and exogenous bovine somatotropin administration. J. Dairy Sci. 94:1917-1921.

Ronchi, B., U. Bernabucci, N. Lacetera, A. V. Supplizi, and A. Nardone. 1999. Distinct and common effects of heat stress and restricted feeding on metabolic status of Holstein heifers. Zoot. Nutr. Anim. 25:75-80.

SAS Institute. 2005. SAS/STAT User's Guide. Release 9.3. SAS Inst. Inc., Cary, NC.

Schelling, G. T. 1984. Monensin mode of action in the rumen. J. Anim. Sci. 58:1518-1527.

Shwartz, G., M. L. Rhoads, M. J. VanBaale, R. P. Rhoads, and L. H. Baumgard. 2009. Effects of a supplemental yeast culture on heatstressed lactating Holstein cows. J. Dairy Sci. 92:935-942.

St. Pierre, N. R., B. Cobanov, and G. Schnitkey. 2003. Economic losses from heat stress by US livestock industries. J. Dairy Sci. 86(E. Suppl.):E52-E77.

Sussman, C. R., and J. L. Renfro. 1997. Heat shock-induced protection and enhancement of $\mathrm{Na}^{+}$-glucose cotransport by LLC-PK1 monolayers. Am. J. Physiol. 273:F530-F537.

Vernon, R. G. 1992. Effects of diet on lipolysis and its regulation. Proc. Nutr. Soc. 51:397-408.

Waldron, M. R., A. E. Kulick, A. W. Bell, and T. R. Overton. 2006. Acute experimental mastitis is not causal toward the development of energy-related metabolic disorders in early postpartum dairy cows. J. Dairy Sci. 89:596-610.

Weiko, J., and W. R. Sherman. 1976. Boroacetylation of carbohydrates. Correlations between structure and mass spectral behavior in monoacetylhexose cyclic boronic esters. J. Am. Chem. Soc. 98:7631-7637.

West, J. W. 1999. Nutritional strategies for managing the heat-stressed dairy cow. J. Anim. Sci. 77(Suppl. 2):21-35.

Wheelock, J. B., R. P. Rhoads, M. J. VanBaale, S. R. Sanders, and L. H. Baumgard. 2010. Effects of heat stress on energetic metabolism in lactating Holstein cows. J. Dairy Sci. 93:644-655. 